\title{
Sporulation of Bremia lactucae Affected by Temperature, Relative Humidity, and Wind in Controlled Conditions
}

\author{
H. Su, A. H. C. van Bruggen, K. V. Subbarao, and H. Scherm
}

First, second, and third authors: Department of Plant Pathology, University of California, Davis 95616; and fourth author: Department of Plant Pathology, University of Georgia, Athens 30602.

Current address of H. Su: Alberta Research Council, Vegreville, Alberta, Canada.

Current address of A. H. C. van Bruggen: Leerstoelgroep Biologische Bedrijfssystemen, 6709 PG Wageningen, The Netherlands.

Accepted for publication 4 December 2003.

\begin{abstract}
Su, H., van Bruggen, A. H. C., Subbarao, K. V., and Scherm, H. 2004. Sporulation of Bremia lactucae affected by temperature, relative humidity, and wind in controlled conditions. Phytopathology 94:396-401.

The effects of temperature ( 5 to $25^{\circ} \mathrm{C}$ ), relative humidity ( 81 to $100 \%$ ), wind speed $\left(0\right.$ to $\left.1.0 \mathrm{~m} \mathrm{~s}^{-1}\right)$, and their interactions on sporulation of Bremia lactucae on lettuce cotyledons were investigated in controlled conditions. Sporulation was affected significantly $(P<0.0001)$ by temperature, with an optimum at $15^{\circ} \mathrm{C}$, and by relative humidity ( $\left.\mathrm{RH}\right)$, with sporulation increasing markedly at $\mathrm{RH} \geq 90 \%$. There was a significant

0.0001) affected the number of cotyledons with sporulation and the number of sporangia produced per cotyledon. No sporulation was observed at wind speeds of $>0.5 \mathrm{~m} \mathrm{~s}^{-1}$, regardless of RH. In still air, the number of sporangiophores produced per cotyledon increased linearly with RH from 81 to $100 \%(P=0.0001, r=0.98)$. Histological observations indicated that sporulation may be affected by stomatal aperture in response to $\mathrm{RH}$, as more closed stomata and correspondingly fewer sporangiophores were present at lower $\mathrm{RH}$. These results are important for understanding the mechanism of RH effects on sporulation and for predicting conditions conducive to downy mildew development.
\end{abstract} effect of exposure time in relation to temperature $(P=0.0007)$ but not to RH. In separate experiments, both RH and wind speed significantly $(P<$

Atmospheric moisture is among the most important environmental factors affecting sporulation of downy mildew pathogens. Peronospora destructor, the causal agent of onion downy mildew, sporulates only at relative humidity $(\mathrm{RH}) \geq 80 \%$ (26). The minimum $\mathrm{RH}$ required for sporulation of other downy mildew pathogens ranges from 90 to $98 \%$ (19). Sporulation of Bremia lactucae Regel, which causes downy mildew of lettuce (Lactuca sativa L.), also requires at least $80 \%$ RH (20).

The temperature range permitting sporulation of $B$. lactucae varies from 4 to $20^{\circ} \mathrm{C}$ (24) with optima reported to range from 10 to $15^{\circ} \mathrm{C}(7)$ or 6 to $11^{\circ} \mathrm{C}(20)$. Although temperature and $\mathrm{RH}$ act simultaneously in the field, the interactive effects of these two variables on sporulation of $B$. lactucae have not been investigated previously.

Wind is involved in various stages of the disease cycle, either alone or by interacting with other factors. Wind can reduce leaf wetness and decrease infection by B. lactucae (21). Multivariate analysis of microclimate data in relation to development of lettuce downy mildew in the field in California suggested that wind at night has a negative effect on disease development (22). Wind also can influence sporulation by affecting RH in the leaf surface boundary layer (8). For example, production of mycelia and conidia by Botrytis cinerea is negatively affected by wind, also depending on atmospheric moisture (23). In saturated still air, sporulation of Drechslera turcica is moderate or abundant, while wind speeds of 0.5 and $1.55 \mathrm{~m} \mathrm{~s}^{-1}$ almost completely prevent sporulation (13). Sporulation of Peronospora destructor is similarly prevented at wind speeds of 0.3 to $1.0 \mathrm{~m} \mathrm{~s}^{-1}$ in saturated air (13). Phytophthora infestans does not produce sporangia at wind

Corresponding author: K. V. Subbarao; E-mail address: kvsubbarao@ucdavis.edu

Publication no. P-2004-0204-01R

(C) 2004 The American Phytopathological Society
Additional keyword: Lactuca sativa. speeds of $0.3 \times 10^{-3} \mathrm{~m} \mathrm{~s}^{-1}$ in 80 to $88 \% \mathrm{RH}$ or at 5.5 to $13.7 \times$ $10^{-3} \mathrm{~m} \mathrm{~s}^{-1}$ in 80 to $95 \%$ RH (9). Similar studies to determine the effect of wind on sporulation of B. lactucae in controlled conditions have not been carried out.

Although individual effects of $\mathrm{RH}$ and wind on sporulation have been well documented for some fungi or oomycetes, our understanding of the mechanism underlying these effects is limited. Leach (12) investigated to what extent sporulation was affected by the electrostatic charge on leaf surfaces analogous to the mechanism underlying spore release. In these studies, a direct electrostatic effect on spore development was considered unlikely (13). Because the sporangiophores of downy mildew pathogens emerge through the stomata, we hypothesized that stomatal aperture, which is affected by $\mathrm{RH}$ and wind $(1,17)$, may indirectly affect sporulation. The objectives of this research were, therefore, to investigate the interactive effects of temperature, $\mathrm{RH}$, and wind speed on sporulation of $B$. lactucae in controlled conditions and to determine the potential mechanism underlying these effects.

\section{MATERIALS AND METHODS}

Maintenance of host and pathogen. Seeds of lettuce cvs. Salinas and Cobham Green were planted in plastic pots ( 5 by 5 by $6 \mathrm{~cm} ; \approx 50$ seeds per pot) containing moist U.C. potting mix $(40 \%$ washed sand, $20 \%$ nitrified red wood compost, $20 \%$ sphagnum peat, and $20 \%$ pumice rock). Seedlings were raised at $15^{\circ} \mathrm{C}$ and $100 \%$ RH in a growth chamber with a 12 -h photoperiod (light intensity of $74 \mathrm{~W} \mathrm{~m}^{-2}$ ) and kept well watered.

An isolate of B. lactucae collected in the Salinas Valley of California in 1991 and belonging to pathotype III (16) was used in the temperature $\times \mathrm{RH}$ experiments. Due to shifts in pathotypes during subsequent years, an isolate belonging to pathotype $\mathrm{V}$, which was dominant in the Salinas Valley in 1997, was used in the $\mathrm{RH} \times$ wind speed experiments. Both isolates were maintained on seed- 
lings of 'Cobham Green' cultured with half-strength Hoagland's solution (10) in sealed tissue culture boxes (GA 7, Magenta Corp., Chicago).

Inoculation. Ten-day-old seedlings were inoculated with a suspension containing $1.0 \times 10^{4}$ sporangia per $\mathrm{ml}$ in sterile distilled water with an atomizer. Unless stated otherwise, inoculated seedlings were kept in a transparent crisper box (32 by 24 by $11 \mathrm{~cm}$ ) for $24 \mathrm{~h}$ at $15^{\circ} \mathrm{C}$ and $100 \% \mathrm{RH}$ in the dark to allow infection.

Effects of temperature and $\mathrm{RH}$ on sporulation. Inoculated seedlings were incubated in crisper boxes at $15^{\circ} \mathrm{C}$ and $100 \% \mathrm{RH}$ with $14 \mathrm{~h}$ light for 4 days. On the fifth day, the boxes were opened to reduce RH to ambient levels (65 to $75 \%$ ) so that sporulation would not occur the following night. On the evening of the sixth day, the experimental treatments were initiated in a splitsplit-plot design with three replicates. Five growth chambers

TABLE 1. Supersaturated salt solutions used to maintain different levels of relative humidity $(\mathrm{RH})$ in experiments on the effect of temperature and $\mathrm{RH}$ on sporulation of Bremia lactucae on lettuce cotyledons in controlled conditions

\begin{tabular}{lccc}
\hline & \multicolumn{3}{c}{$\mathrm{RH}(\%)^{\mathrm{a}}$} \\
\cline { 2 - 4 } Temperature $\left({ }^{\circ} \mathrm{C}\right)$ & 85 & 90 & 95 \\
\hline 5 & $\mathrm{KBr}$ & $\mathrm{KCl}$ & $\mathrm{KNO}_{3}$ \\
10 & $\mathrm{KBr}$ & $\mathrm{KCl}$ & $\mathrm{KNO}_{3}$ \\
15 & $\mathrm{KCl}$ & $\mathrm{MgSO}_{4} \cdot 7 \mathrm{H}_{2} \mathrm{O}$ & $\mathrm{KNO}_{3}$ \\
20 & $\mathrm{KCl}$ & $\mathrm{MgSO}_{4} \cdot 7 \mathrm{H}_{2} \mathrm{O}$ & $\mathrm{KH}_{2} \mathrm{PO}_{4}$ \\
25 & $\mathrm{KCl}$ & $\mathrm{MgSO}_{4} \cdot 7 \mathrm{H}_{2} \mathrm{O}$ & $\mathrm{KH}_{2} \mathrm{PO}_{4}$ \\
\hline
\end{tabular}

${ }^{a}$ An $\mathrm{RH}$ level of $100 \%$ was maintained with double-distilled water at all temperatures.
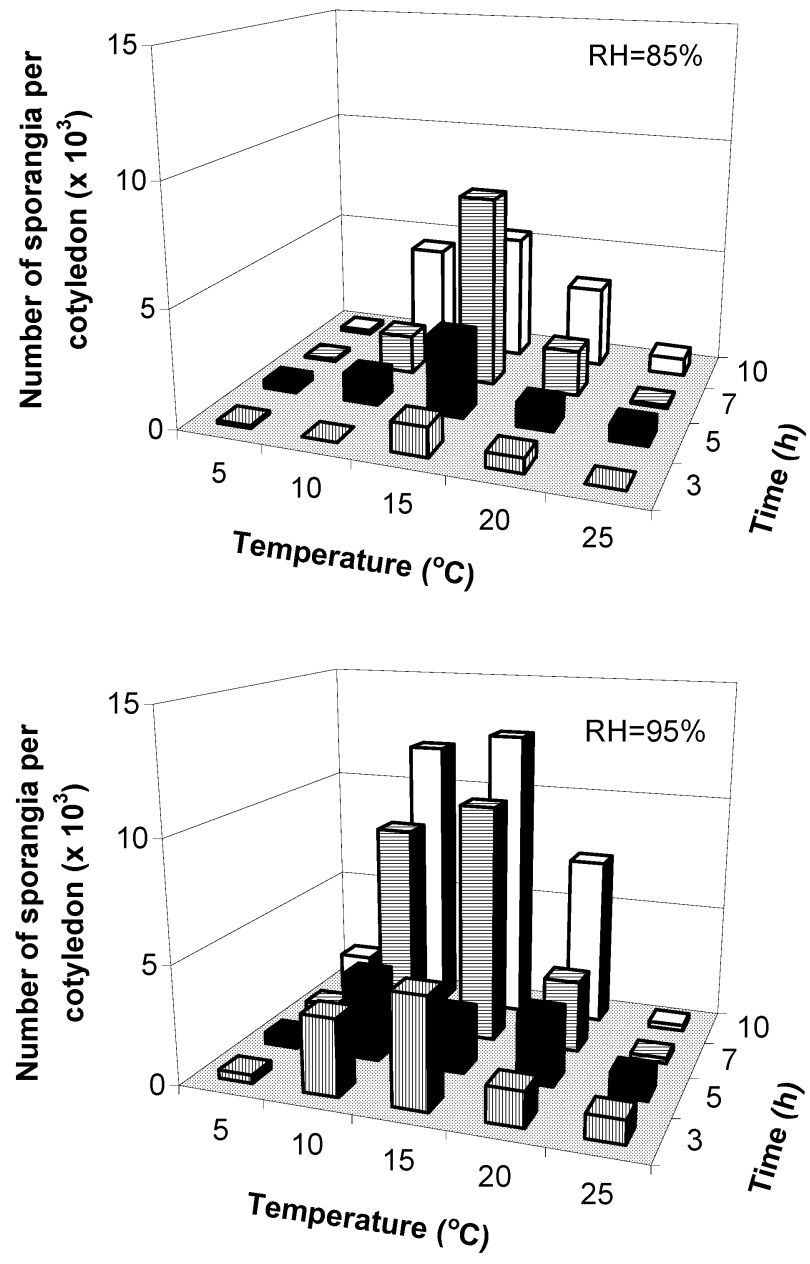

Fig. 1. Effects of temperature and relative humidity $(\mathrm{RH})$ on the production of sporangia by Bremia lactucae on lettuce cotyledons after exposure times of 3,5 , 7 , and $10 \mathrm{~h}$ in darkness. Data are the means of two experiments, each with 100 cotyledons per treatment.

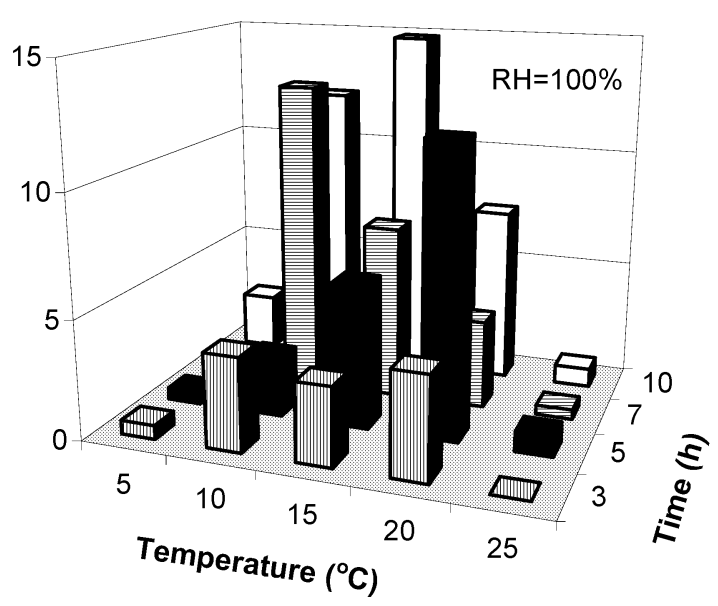

(main-plots) were used for temperature treatments of $5,10,15$, 20 , and $25^{\circ} \mathrm{C}$. RH $(85,90,95$, and $100 \%)$ and exposure time $(3$, 5,7 , and $10 \mathrm{~h}$ ) were allocated to subplots and sub-subplots, respectively. The different RH levels were maintained with supersaturated salt solutions (3) (Table 1) and measured periodically with a humidity probe (Model 207; Campbell Scientific Inc., Logan, UT). The experiment was carried out twice.

The number of sporangia produced per cotyledon was assessed after exposure times of $3,5,7$, and $10 \mathrm{~h}$ in the various temperature and RH combinations. All cotyledons were harvested, and the sporangia were washed off by vortexing the cotyledons in $5 \mathrm{ml}$ of water. Concentrations of sporangial suspensions were determined with a hemacytometer and expressed as number of sporangia per cotyledon.

Effects of RH and wind speed on sporulation. Miniature wind tunnels were constructed from crisper boxes and plastic tubing. Two fans were attached individually to two $5.5-\mathrm{cm}$-diameter openings on one side of the box. The front of each fan was fastened to the box with glue and its back was connected to plastic tubing leading to an opening of the same diameter on the opposite side of the box. Wind was generated with the fans from one end of the box and passed through the box into the open end of the tubing at the opposite side. This design maintained a sealed air-circulation system with constant RH. Potentiometers were used to adjust fan speed and thereby change wind speed inside the box. Each wind tunnel was divided longitudinally with a plastic board, allowing the establishment of two independent wind treatments while maintaining the same RH. RH was measured as described previously.

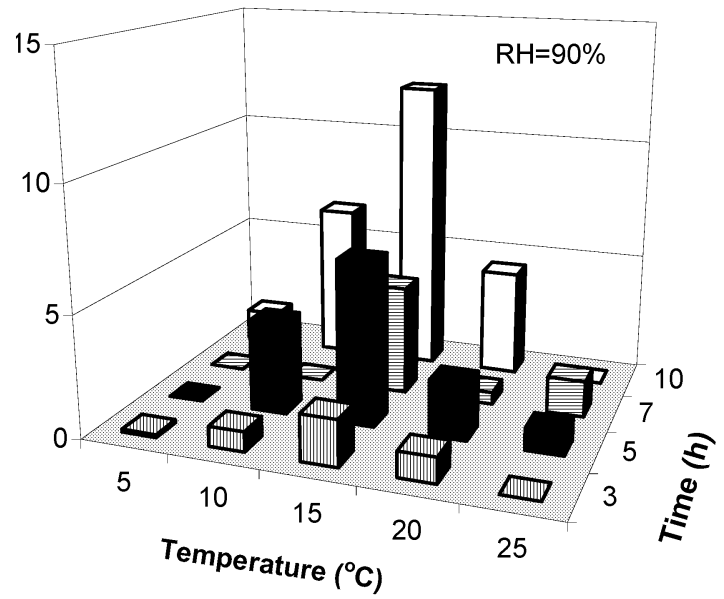

Vol. 94, No. 4, 2004 
A split-plot design with three replicates was used to investigate the interactive effects of RH (main plot) and wind speed (subplot) on sporulation of B. lactucae. Wind tunnels were maintained at $15^{\circ} \mathrm{C}$, and supersaturated solutions of $\left(\mathrm{NH}_{4}\right)_{2} \mathrm{SO}_{4}$, $\mathrm{ZnSO}_{4} \cdot 7 \mathrm{H}_{2} \mathrm{O}, \mathrm{Na}_{2} \mathrm{SO}_{3} \cdot 7 \mathrm{H}_{2} \mathrm{O}$, and double-distilled water were used to generate $81,90,95$, and $100 \% \mathrm{RH}$, respectively. Wind speeds of $0,0.1,0.5$, and $1.0 \mathrm{~m} \mathrm{~s}^{-1}$ were set for each RH treatment and measured inside the tunnel at $6 \mathrm{~cm}$ from the fans with a lowvelocity flow analyzer (Type 54N50; DANTEC, Skovlunde, Denmark).

When one pot with 50 plants was moved into each section of the wind tunnel at a distance of $6 \mathrm{~cm}$ from the fan, seedlings were inoculated as described previously and incubated at $100 \% \mathrm{RH}$ and $15^{\circ} \mathrm{C}$ with $12 \mathrm{~h}$ light for 3 days. After 3 days of exposure to the combined $\mathrm{RH} \times$ wind treatments, cotyledons were harvested and assessed for sporulation as described previously. The experiment was carried out three times.

Effect of RH on sporangiophore formation. RH levels of 81, 90,95 , and $100 \%$ at $15^{\circ} \mathrm{C}$ were established in crisper boxes as described previously. Inoculated seedlings were moved into the boxes after they had been incubated for 3 days at $15^{\circ} \mathrm{C}$ and $100 \%$ $\mathrm{RH}$ with $12 \mathrm{~h}$ light. After 3 days, 15 cotyledons in each experiment with sporulation were randomly collected from the various $\mathrm{RH}$ treatments in three experiments, and the number of sporangiophores produced on the upper surface was counted under a stereomicroscope at $\times 50$.

Effect of RH on stomatal aperture and sporangiophore emergence. To investigate whether $\mathrm{RH}$ affects stomatal aperture, which, in turn, may affect emergence of sporangiophores, inoculated seedlings were incubated in crisper boxes at $15^{\circ} \mathrm{C}$ and 81,90 , and $100 \% \mathrm{RH}$ with $12 \mathrm{~h}$ light. At midnight of the third day after inoculation, replicas of cotyledon surfaces were prepared following the procedure of Williams and Green (25). Ten replicas were made from each of 10 cotyledons selected randomly from seedlings in each of the three $\mathrm{RH}$ treatments.

TABLE 2. Split-split-plot analysis of variance of the effect of temperature, relative humidity (RH), and exposure time on the number of sporangia produced by Bremia lactucae on lettuce cotyledons in controlled conditions $^{\mathrm{a}}$

\begin{tabular}{lrcc}
\hline Source & df & Mean square & $P>F$ \\
\hline Temperature & 4 & 775.10 & 0.0001 \\
RH & 3 & 216.22 & 0.0001 \\
Temperature $\times$ RH & 12 & 36.28 & 0.0762 \\
Time & 3 & 355.45 & 0.0001 \\
Temperature $\times$ time & 12 & 63.99 & 0.0007 \\
RH $\times$ time & 9 & 18.51 & 0.5778 \\
Temperature $\times$ RH $\times$ time & 36 & 10.93 & 0.9939 \\
\hline
\end{tabular}

a Analysis was conducted on pooled data after the preliminary analysis revealed no treatment $\times$ experiment interaction.

TABLE 3. Split-plot analysis of variance of the effect of relative humidity (RH) and wind speed on the percentage of cotyledons with sporulation and the number of sporangia produced by Bremia lactucae on lettuce cotyledons in controlled conditions ${ }^{\mathrm{a}}$

\begin{tabular}{lccrr}
\hline Variable & Source & df & Mean square & $P>F$ \\
\hline Percentage of cotyledons & & & & \\
$\quad$ with sporulation & RH & 3 & $2,260.2$ & 0.0001 \\
& Wind & 3 & $4,563.1$ & 0.0001 \\
& RH $\times$ wind & 9 & 641.5 & 0.0001 \\
Number of sporangia & RH & 3 & 788.7 & 0.0001 \\
per cotyledon & Wind & 3 & $1,384.4$ & 0.0001 \\
& RH $\times$ wind & 9 & 234.9 & 0.0001 \\
\hline
\end{tabular}

a Analysis was conducted on pooled data after the preliminary analysis revealed no treatment $\times$ experiment interaction.
Molds were examined microscopically, and numbers of open and closed stomata and stomata with sporangiophores were recorded.

Data analysis. Effects of temperature, $\mathrm{RH}$, and exposure time on the number of sporangia per cotyledon were analyzed using analysis of variance for a split-split-plot design in SAS version 6.09 (SAS Institute, Cary, NC). Effects of RH and wind speed on the incidence of cotyledons with sporulation and the number of sporangia per cotyledon were analyzed similarly using a split-plot design. The effect of $\mathrm{RH}$ on the number of sporangiophores produced per cotyledon was analyzed using linear regression analysis.

\section{RESULTS}

Effects of temperature and RH on sporulation. Temperature had a highly significant effect on sporulation (Fig. 1; Table 2), and maximum sporulation occurred at $15^{\circ} \mathrm{C}$ for most exposure times. There was a significant interaction between temperature and time (Table 2), with sporulation being favored by longer periods at optimum temperatures. RH also significantly affected sporulation, whereby increases in RH favored production of sporangia particularly at $\mathrm{RH} \geq 90 \%$ (Fig. 1). There were no interactions between $\mathrm{RH}$ and temperature or between $\mathrm{RH}$ and exposure time (Table 2).
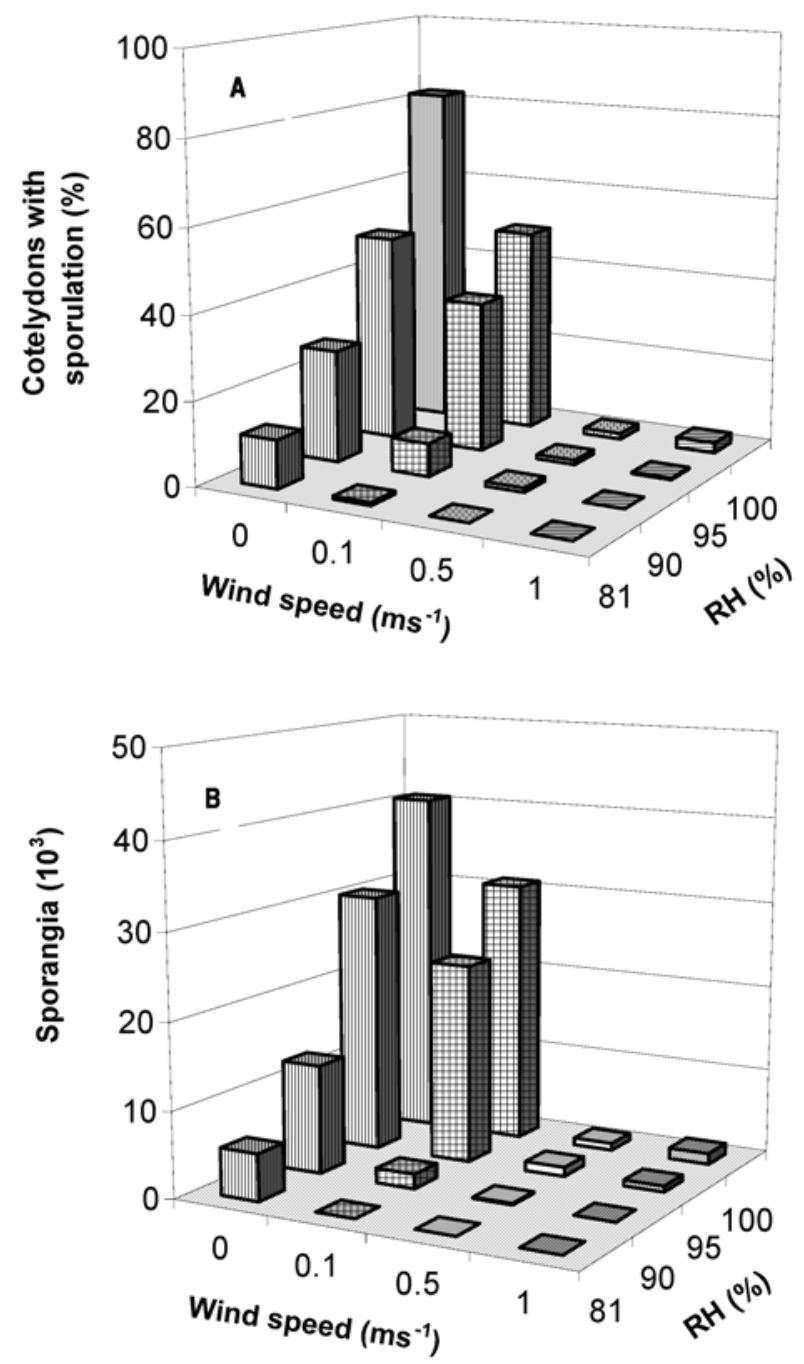

Fig. 2. Effects of wind speed and relative humidity $(\mathrm{RH}) \mathbf{A}$, on the percentage of cotyledons with sporulation and $\mathbf{B}$, on the number of sporangia produced by Bremia lactucae on lettuce cotyledons. Data are the means of three experiments, each with 100 cotyledons per treatment. 
Effects of RH and wind speed on sporulation. RH, wind speed, and their interactions significantly affected sporulation of B. lactucae (Table 3). Wind speeds of $\geq 0.5 \mathrm{~m} \mathrm{~s}^{-1}$ inhibited sporulation at all RH treatments tested, as measured by the incidence of cotyledons with sporulation (Fig. 2A). At wind speeds of $<0.5 \mathrm{~m} \mathrm{~s}^{-1}$, the number of cotyledons with sporulation increased exponentially with increasing $\mathrm{RH}$.

The number of sporangia produced per cotyledon at lower wind speeds also increased sharply as $\mathrm{RH}$ increased from 81 to $100 \%$ (Fig. 2B). No sporangia were produced for wind speeds of $\geq 0.1 \mathrm{~m} \mathrm{~s}^{-1}$ at RH $81 \%$ and of $\geq 0.5 \mathrm{~m} \mathrm{~s}^{-1}$ at any RH. There was a significant interaction between wind speed and RH (Table 3), with most sporangia produced at lower wind speeds and higher RH (Fig. 2B).

Effect of RH on sporangiophore formation. The number of sporangiophores per cotyledon increased linearly with increasing RH $(P=0.0001, r=0.98$; Fig. 3$)$. The average number of sporangiophores produced on the upper surface of an individual cotyledon at $100 \% \mathrm{RH}$ was $121 \pm 22.7$ (mean $\pm \mathrm{SD}$ ). Since the upper surface of a cotyledon contained about 700 stomata, as estimated by the mold-cast replicas, less than $20 \%$ of all stomata on cotyledons harbored sporangiophores.

Effect of RH on stomatal aperture and sporangiophore emergence. The status of stomata on lettuce cotyledon surfaces could be replicated reliably with the mold-cast technique (Fig. 4). RH affected stomatal aperture (Fig. 5), with more stomata closed at $81 \%$ than at 90 or $100 \%$ RH. Correspondingly, there were fewer stomata with sporangiophores at 81 or $90 \%$ than at $100 \%$ $\mathrm{RH}$. The maximum frequency of stomata harboring sporangiophores was $15.1 \pm 7.2 \%$ of the total number of stomata.

\section{DISCUSSION}

The optimum temperature range for sporulation of B. lactucae was between 10 and $20^{\circ} \mathrm{C}$ in this study; this is similar to the range reported by Grogan et al. (7) for isolates from California (10 to $15^{\circ} \mathrm{C}$ ), but higher than that observed by Powlesland (20) for isolates from the United Kingdom $\left(6\right.$ to $\left.11^{\circ} \mathrm{C}\right)$. Amongst others, temperature may affect sporulation of downy mildew pathogens via its effect on vegetative growth of sporangiophores. For example, sporangiophores of Peronospora destructor were

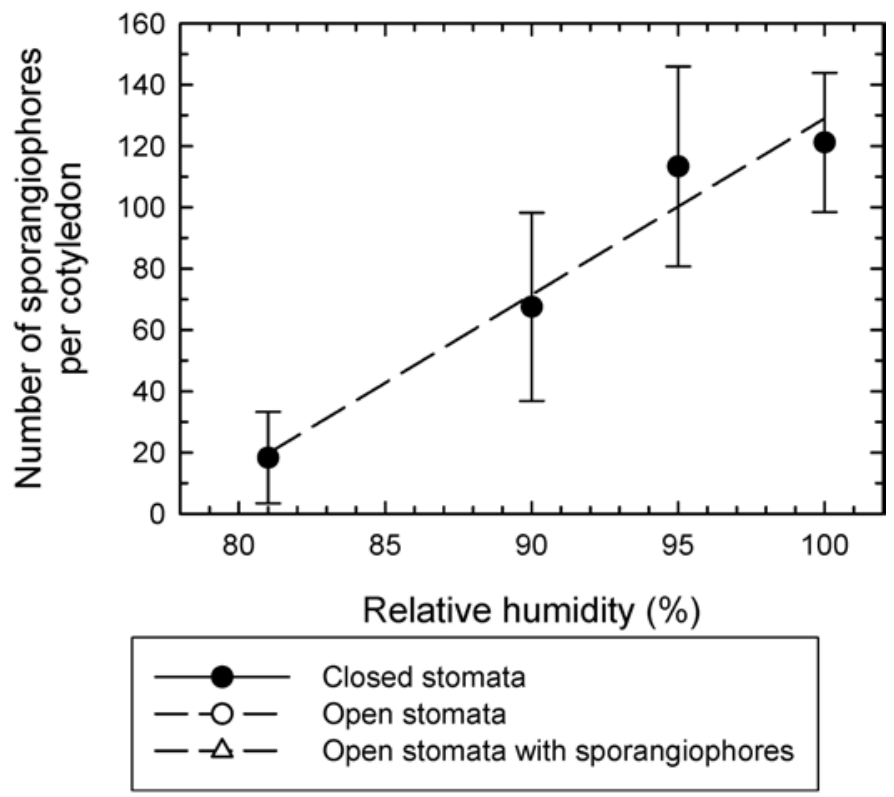

Fig. 3. Effect of relative humidity on the production of sporangiophores by Bremia lactucae on lettuce cotyledons. Data are means and standard deviations of 15 cotyledons per treatment. shorter at suboptimal and supraoptimal temperatures than at the optimal temperature of $13^{\circ} \mathrm{C}(26)$. It took $\approx 6$ to $9 \mathrm{~h}$ for Pseudoperonospora cubensis (11) and $\approx 8 \mathrm{~h}$ for Peronospora trifoliorum (5) to emerge from stomata completely and form mature sporangiophores. This elongation period is a function of temperature.

Sporulation of B. lactucae was reduced at lower RH. Indeed, the number of sporangiophores formed was reduced significantly as RH dropped below saturation, and this may have been the main reason for the reduction in sporangial numbers at lower $\mathrm{RH}$. The response of $B$. lactucae to decreasing $\mathrm{RH}$ was similar to that ob-
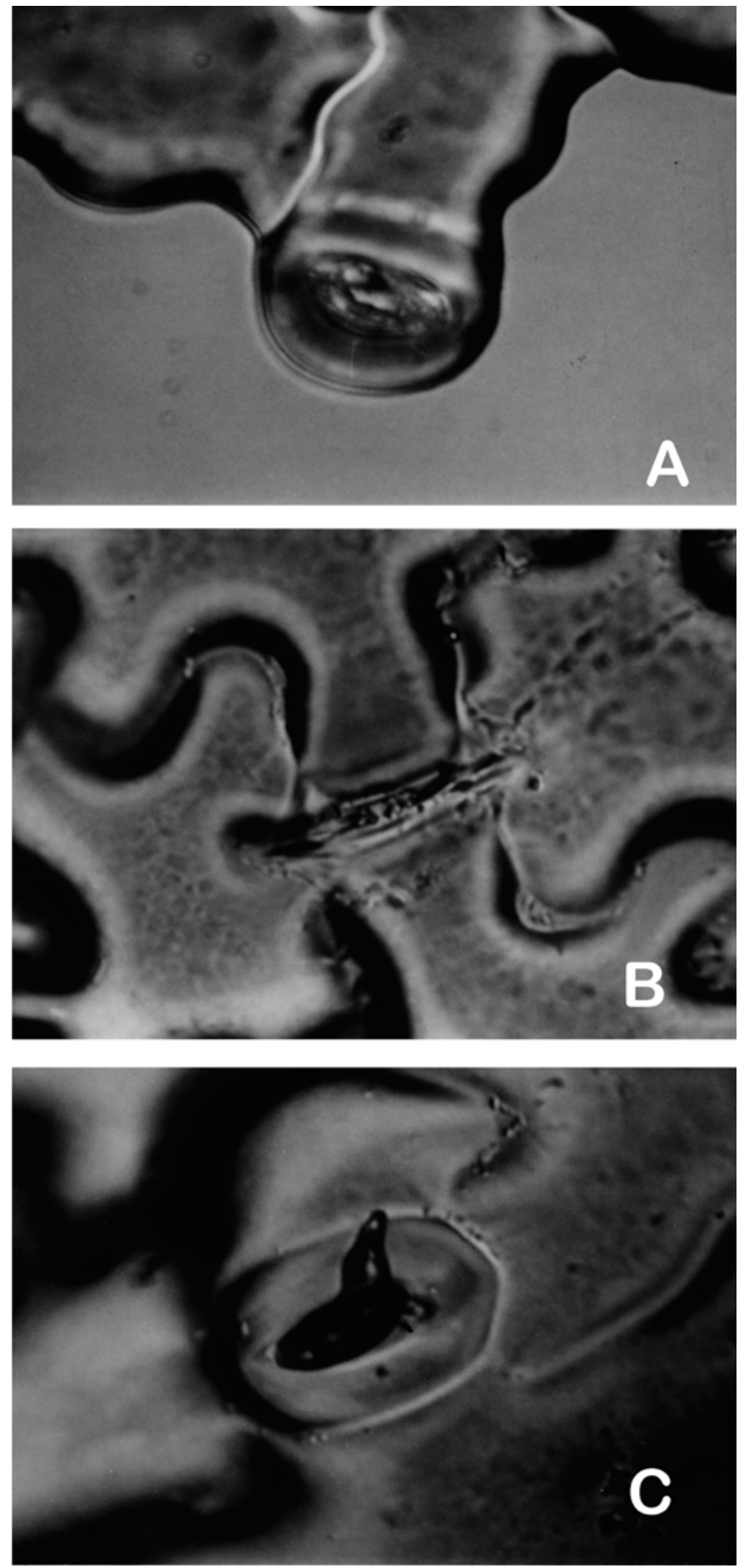

Fig. 4. Replicas of stomata on the adaxial surface of lettuce cotyledons obtained with the mold-cast technique and showing $\mathbf{A}$, an open stoma, $\mathbf{B}$, a closed stoma, and $\mathbf{C}$, a stoma with an emerging sporangiophore of Bremia lactucae $(\times 500)$ 
served for other downy mildew pathogens. No significant difference in sporulation of Peronospora tabacina was observed when RH ranged from 97 to $100 \%$. When RH dropped below 96\%, however, sporulation decreased rapidly and approached zero as RH approached $90 \%$ (2). Sporulation of Peronospora destructor required similar high-RH conditions (26). Other downy mildew pathogens need even higher RH for initiation of sporulation (19).

When wind speeds exceeded $0.1 \mathrm{~m} \mathrm{~s}^{-1}$, sporulation of B. lactucae was reduced, whereas wind speeds of $\geq 0.5 \mathrm{~m} \mathrm{~s}^{-1}$ inhibited sporulation completely. This could explain previous observations that wind at night tended to reduce downy mildew incidence in the field (23). We observed a significant interaction between wind speed and RH. Wind can reduce RH near the leaf surface, increase the transpiration rate (6), and thus may potentially inhibit sporulation (8). An interactive effect of wind and RH on sporulation was reported previously for Phytophthora infestans (9) and Botrytis cinerea (23). Given the requirement for RH near saturation for sporulation of downy mildew pathogens, it is not surprising that even relatively low wind speeds can reduce RH to levels below the threshold for sporulation.

The maximum number of sporangiophores produced on the upper surface of individual cotyledons at $100 \% \mathrm{RH}$ in our study was very close to the value of 120 sporangiophores per cotyledon estimated by Eenink and DeJong (4) for lettuce cultivars lacking resistance to downy mildew. The percentage of stomata harboring sporangiophores estimated by our mold-cast replicas also was similar to that obtained from direct counts of sporangiophores under a stereomicroscope, indicating that identification and enumeration of sporangiophores from the replicas was reliable.

An association between decreased numbers of closed stomata and increased numbers of stomata with sporangiophores per cotyledon was observed as RH increased from 81 to $100 \%$. We hypothesize that more sporangiophores form through open stomata that are more numerous at higher $\mathrm{RH}$, and that the reduction in $\mathrm{RH}$ increased the number of closed stomata and hence reduced the chance for the emergence of sporangiophores. If open stomata were randomly distributed on the cotyledon surfaces, their availability should not be a limitation for sporulation, and the prob-
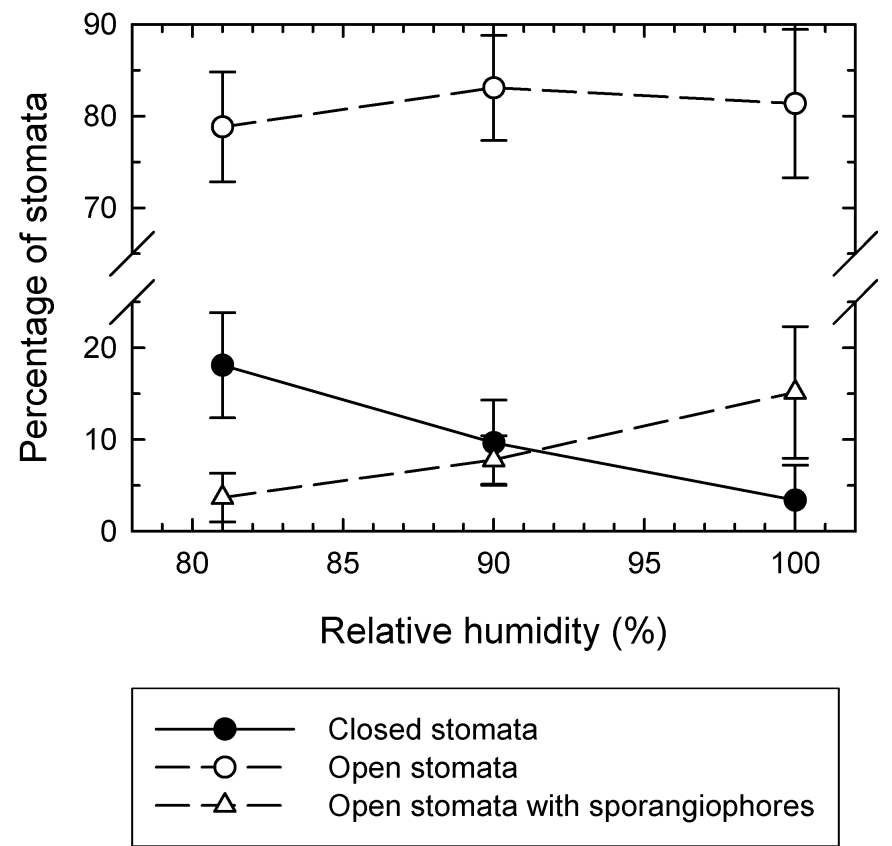

Fig. 5. Effect of relative humidity on the percentage of closed stomata and of open stomata with or without sporangiopores of Bremia lactucae on lettuce cotyledons. Data are means and standard deviations of 10 replicas per treatment. abilities for sporangiophores to emerge through stomata at different RH levels should be similar. However, our results showed that only a small proportion of open stomata actually harbored sporangiophores, and that this proportion increased from $3.7 \%$ at $81 \% \mathrm{RH}$ to $15.1 \%$ at $100 \% \mathrm{RH}$. This may be due to restricted vegetative growth of mycelia of the pathogen among leaf mesophyll cells (15), possibly due to nutrient or space limitations. Furthermore, open stomata are in fact not uniformly distributed on the leaf surface (18), and their patchy arrangement could greatly reduce the opportunity for sporangiophores to emerge. Although as many as 10 sporangiophores of Peronospora schachtii were able to emerge from a single stoma on a beet leaf (14), a similar pattern was not commonly observed for B. lactucae. Thus, multiple sporangiophores per stoma are unlikely to compensate for the reduction in the number of stomata harboring sporangiophores.

\section{ACKNOWLEDGMENTS}

This study was funded by USDA-NRI grant 96-35313-3752 to A. H. C. van Bruggen, K. V. Subbarao, and R. W. Michelmore. We thank J. Jernstedt for assistance with the mold-cast technique and O. Ochoa for providing some of the lettuce seeds and the pathotype III isolate of B. lactucae.

\section{LITERATURE CITED}

1. Aphalo, P. J., and Jarvis, P. G. 1991. Do stomata respond to relative humidity? Plant Cell Environ. 14:127-132.

2. Cruickshank, I. A. M. 1958. Environment and sporulation in phytopathogenic fungi. 1. Moisture in relation to the production and discharge of conidia of Peronospora tabacina Adam. Aust. J. Biol. Sci. $11: 162-170$.

3. Dhingra, O. D., and Sinclair, J. B. 1995. Basic Plant Pathology Methods. 2nd ed. Lewis Publishers, Boca Raton, FL.

4. Eenink, A. H., and DeJong, C. J. 1982. Partial resistance in lettuce to downy mildew (Bremia lactucae). 3. Correspondence between resistance levels of cotyledons and leaf discs and resistance of adult plants. Euphytica 31:761-770.

5. Fried, P. M., and Stuteville, D. L. 1977. Peronospora trifoliorum sporangium development and effects of humidity and light on discharge and germination. Phytopathology 67:890-894.

6. Grace, J., Malcoln, D. C., and Bradbury, I. K. 1975. The effect of wind and humidity on leaf diffusive resistance on sitka spruce seedlings. J. Appl. Ecol. 12:931-940.

7. Grogan, R. G., Snyder, W. C., and Bardin, R. 1955. Diseases of lettuce. Calif. Agric. Exp. Stn. Circ. 448:14-15.

8. Harrison, J. G. 1992. Effects of the aerial environment on late blight of potato foliage-A review. Plant Pathol. 41:384-416.

9. Harrison, J. G., and Lowe, R. 1989. Effects of humidity and air speed on sporulation of Phytophthora infestans on potato leaves. Plant Pathol. 38:585-591.

10. Hoagland, D. R., and Arnon, D. I. 1938. The water-culture method for growing plants without soil. Calif. Agric. Exp. Stn. Circ. 347:1-31.

11. Kajiwara, T., and Iwata, Y. 1957. Observations on the sporulation of cucumber downy mildew fungus. Ann. Phytopathol. Soc. Jpn. 22:201203.

12. Leach, C. M. 1975. An electrostatic theory to explain violent spore liberation by Drechslera turcica and other fungi. Mycologia 68:63-86.

13. Leach, C. M. 1985. Effect of still and moving moisture-saturated air on sporulation of Drechslera and Peronospora. Trans. Br. Mycol. Soc. 84:179-183.

14. Leach, L. D. 1931. Downy mildew of the beet, caused by Peronospora schachtii Fuckel. Hilgardia 6:203-251.

15. Michelmore, R. W. 1981. Sexual and asexual sporulation in the downy mildews. Pages 165-181 in: The Downy Mildews. D. M. Spencer, ed. Academic Press, New York.

16. Michelmore, R. W. 1982. A method for determining the virulence phenotype of Bremia lactucae isolates. Trans. Br. Mycol. Soc. 79:542-546.

17. Mott, K., and Parkhurst, D. F. 1991. Stomatal responses to humidity in air and helox. Plant Cell Environ. 14:509-515.

18. Mott, K. A., Cardon, Z. G., and Berry, J. A. 1993. Asymmetric patchy stomatal closure for the two surfaces of Xanthium strumarium L. leaves at low humidity. Plant Cell Environ. 16:25-34.

19. Populer, C. 1981. Epidemiology of downy mildews. Pages 57-105 in: The 
Downy Mildews. D. M. Spencer, ed. Academic Press, New York.

20. Powlesland, R. 1954. On the biology of Bremia lactucae. Trans. Br. Mycol. Soc. 37:362-371.

21. Scherm, H., and van Bruggen, A. H. C. 1993. Response surface models for germination and infection of Bremia lactucae, the fungus causing downy mildew of lettuce. Ecol. Model. 65:281-296.

22. Scherm, H., and van Bruggen, A. H. C. 1994. Weather variables associated with infection of lettuce by downy mildew (Bremia lactucae) in coastal California. Phytopathology 84:860-865.
23. Thomas, C. S., Marois, J. J., and English, J. T. 1988. The effect of wind speed, temperature, and relative humidity on development of aerial mycelium and conidia of Botrytis cinerea on grape. Phytopathology 78:260-265.

24. Verhoeff, K. 1960. On the parasitism of Bremia lactucae Regel on lettuce. Tijdschr. Plantenziekten. Liekten 66:133-203.

25. Williams, M. H., and Green, P. B. 1988. Sequential scanning electron microscopy of a growing plant meristem. Protoplasma 147:77-79.

26. Yarwood, C. E. 1943. Onion downy mildew. Hilgardia 14:595-691. 